\title{
NOTICES OF PUBLICATIONS
}

\author{
by WERNER GREUTER*
}

\section{OPTIMA}

Benito VALDÉS - Results of the fifth "Iter Mediterraneum" in Morocco, 827 June, 1992. [Bocconea (ISSN 11204060, print; 2280-3882, online), 26.] Herbarium Mediterraneum Panormitanum, Palermo, 2013 (ISBN 978-887915-026-2). 179 pages, 6 photographs, 8 figures, 2 maps, 2 tables; paper. [Received fall 2013].

The long awaited account of OPTIMA's 1992 Iter Mediterraneum, with a full list of the 2366 vascular plant gatherings made, plus partial lists for lichens (by Stephen Jury) and bryophytes (by P. Campisi \& al.) as well as chromosome counts for 111 of the collected taxa (by Zoila Díaz \& Raquel Parra). New combinations are proposed in Astragalus, Malva, Nepeta, and Ornithogalum.

Gianniantonio DoMINA, Werner GREUTER \& Francesco Maria RAIMONDO (ed.) - XIV OPTIMA Meeting, September, 9-15, Palermo. Abstracts. OPTIMA, Palermo, 2013 (ISBN 978-88903108-8-1). 165 pages [+ page 21 (cancellans), 166-172], 1 table; paper [+ 4 loose sheets]. [Received fall 2013].

Includes the final version of the scientific programme of the Meeting as well as the abstracts of 82 lectures and 67 poster presentations, extended versions of which are due to be published in forthcoming volumes of the journal Flora mediterranea. Available online at: http://www.optima-bot.org/meetings/ XIVAbstracts.pdf

\section{Cryptogams}

Flora liquenológica ibérica, 1-10 [received fall 2013]:

Ana Rosa Burgaz \& Isabel Martínez - Peltigerales: Lobariaceae, Nephromataceae, Peltigeraceae. [Flora liquenológica ibérica (ISSN 1696-0513), [1].] - Sociedad Española de Liquenología, Murcia, 2003. 61 pages, 10 plates of drawings, map; paper.

Regina Carballal \& María Eugenia LÓPEZ DE SILANES - Ostropales: Graphidaceae, Solorinellaceae. [Flora liquenológica ibérica (ISSN 1696-0513), [2].] - Sociedad Española de Liquenología, Murcia, 2004. 48 pages, 9 plates of drawings, map; paper.

Esteve LLOP - Lecanorales: Bacidiaceae I, Bacidia y Bacidina. [Flora liquenológica ibérica (ISSN 1696-0513), [3].] - Sociedad Española de Liquenología, Barcelona, 2007. 49 pages, 5 figures (drawings +18 colour photographs), map; paper.

All unsigned texts are by Werner Greuter. Please send all items for announcement or review directly to the column editor: Prof. W. Greuter, Herbarium Mediterraneum, Giardino Botanico, Via Lincoln 2/A, I-90123 Palermo. 
Publications

Ana Rosa Burgaz \& Teuvo Ahti Cladoniaceae. [Flora liquenológica ibérica (ISSN 1696-0513), 4.] - Sociedad Española de Liquenología, Madrid, 2009. 111 pages, 21 plates of drawings, 83 maps; paper.

Mireia GIRALT - Physciaceae I, Endohyalina, Rinodina y Rinodinella. [Flora liquenológica ibérica (ISSN 1696-0513), 5.] - Sociedad Española de Liquenología, Barcelona, 2010. 105 pages, 22 figures (drawings +21 grayscale or colour photographs), table, map; paper.

Regina CARBALLAL \& varying authors - Pannariaceae. [Flora liquenológica ibérica (ISSN 1696-0513), 6.] - Sociedad Española de Liquenología, Pontevedra, 2010. 44 pages, 9 plates of drawings, map; paper.

Diana MuÑIz \& Néstor L. HLADUN Calicioides. [Flora liquenológica ibérica (ISSN 1696-0513), 7.] - Sociedad Española de Liquenología, Barcelona, 2011. 95 pages, 96 photographs (mostly in colour), map; paper.

Ana Rosa Burgaz - Peltigerales: Massalongiaceae y Placynthiaceae. [Flora liquenológica ibérica (ISSN 1696-0513), 8.] - Sociedad Española de Liquenología, Madrid, 2011. 42 pages, 20 colour photographs, 17 maps; paper.

Víctor J. RICO \& José María BARRASA - Basidiomycota liquenizados y liquenícolas. Agaricales: Hygrophoraceae, Arrhenia y Lichenomphalia; Cantharellales: Clavulinaceae, Multiclavula; Hydnaceae, Burgoa. [Flora liquenológica ibérica (ISSN 1696-0513), 9.] Sociedad Española de Liquenología, Madrid, 2011.48 pages, 15 photographs (mostly in colour), map; paper.
Palmira CARvalho - Collema. [Flora liquenológica ibérica (ISSN 1696-0513), 10.] - Sociedad Española de Liquenología, Pontevedra, 2012. 52 pages, 8 plates of figures (drawings and photographs), map; paper.

Started in the early years of this millennium, the national compendium of lichens in the Iberian Peninsula has been making good and steady progress so far. It is being produced by slim volumes, perhaps rather fascicles, if and when a treatment is ready. The first volume was published in 2003. To quote from its presentation (in OPTIMA Newslett. 38: (5-6). 2008): "The new Flora is being based on Llimona \& Hladun's 2001 inventory of Iberian lichen-forming and lichenicolous fungi (see OPTIMA Newslett. 36: (3). 2002). Its treatments are of an exemplary, submonographic style, with full keys, high-standard nomenclatural treatment (except that no types are cited for synonyms), detailed taxon descriptions and copious illustration, by original drawings, of a majority if not all of the species. Distribution (both overall and by Iberian provinces) is summarised but not mapped. Ample space is given to observations of all kind. The language adopted is Spanish." - To which one might add that many subsequent volumes ([3], 5, 7-10) use micrographs and colour photographs for illustration purposes, and two (4 and 8) include distribution maps for species.

Mathias Vust, Philippe Clerc, Christine Habashi \& Jean-Claude MerMILLIOD - Liste rouge des lichens du canton de Genève. [Publication horssérie $n^{\circ}$ 16.] - Conservatoire et Jardin botaniques de la Ville de Genève, [Chambésy], 2015 (ISBN 978-2-8277- 
0132-2). 160 pages, numerous colour photographs, graphs, maps, tables; laminated cover. [received March 2015.]

The title is a blatant understatement, for at least three reasons. First, the book includes a complete inventory of the Canton of Geneva's lichens: 612 species, not counting 66 that were omitted for either having been reported by error (of location or identification), or being impossible to interpret, or not being lichens. Second, it is an all but complete compendium of regional lichenology, with a concise introduction to the discipline, an historical account, and a description of the principal lichen habitats - of which the one that figures most prominently, and has received particular attention, are tombstones in cemeteries. Third, it is generously and beautifully illustrated (sadly, I have been unable to find any reference to or acknowledgement of the authors or source of the illustrations; the fact that one of the authors has been portrayed handling a camera being the only, cryptic hint). The progress of knowledge embodied in the text is amazing: a Swiss inventory of 2004 had listed 283 lichen species for Geneva, to which 329 are added here. Not all have been found again during the 10 years of field inventorying by the author team: 143, almost one quarter, are reported as missing and classified either as data deficient or regionally extinct. Another quarter is placed in one of the threat categories: critically endangered, endangered or vulnerable. All in all, the book can be qualified as pioneering a new generation of modern, comprehensive, informative and educational regional Red Data Books.
Luis Alberto Parra SANCHez - Agaricus L., Allopsalliota Nauta \& Bas, part II. [Fungi Europaei, 1A.] - Candusso, Alassio, 2013 (978-88-905310-2-6). 1168 pages, 616 photographs or micrographs in colour, 119 figures in blackand-white, 67 coloured plates (mostly facsimiles) tables; hard cover. [89€; received December 2013.]

The second part of Parra's monumental monograph of European Agariceae encompasses the treatment of the remaining 6 sections and 55 species of Agaricus (12 newly described here) plus the unispecific genus Allopsalliota. Same as the first part (see OPTIMA Newslett. 38: (5-6). 2009), the text is fully bilingual (Spanish and English) except for the trilingual keys where Italian is added, extremely detailed in its descriptive and corollary matter, superbly and generously illustrated. The average treatment for a species extends over 11 pages of text and 9 of colour illustrations. At the end, preceding the indexes, there is an exhaustive, annotated list of names that were not validly published or had been misapplied, so that on the whole the monograph also serves as a critical nomenclator for the genus.

\section{Gymnosperms}

Robert P. Adams - Junipers of the world: The genus Juniperus. $4^{\text {th }}$ edition. - Trafford, Bloomington, 2014 (ISBN 978-1-4907-2325-9). $v+415$ pages, numerous black-and-white illustrations (photographs, maps, graphs), tables; laminated cover [hard back edition announced]. [29.95 US\$; received May 2014.]

Remarkable: a monograph published in four editions within a 10-years' span; 
Publications

each edition including substantial changes, improvements in taxonomic concepts, mostly based on the author's ongoing research on the World's junipers. As compared to ed. 3 (see OPTIMA Newslett. 40: (3). 2011), there has been one major change affecting Mediterranean Juniperus species. What used to be an ill-defined variety based exclusively on fruit morphology, J. phoenicea var. turbinata, found in disseminated localities within the circummediterranean area of J. phoenicea var. phoenicea, turns out to be a species of its own, $J$. turbinata, an almost complete vicariant to $J$. phoenicea and much more widespread than the latter. Uncharacteristically for a species so named, and on the assumption that the identity of the Linnean type has been correctly assessed, $J$. phoenicea proper now appears to be confined to E Spain and S. France, just extending to NW Italy in the Maritime Alps.

\section{Phanerogams}

Pierre Coulot \& Philippe Rabaute Monographie des Leguminosae de France. Tome 3 - Tribu des Trifolieae. [Bulletin de la Société Botanique du Centre-Ouest, Numéro spécial [ISSN 0759934x), 40.] - Société Botanique du Centre-Ouest, Jarnac, 2013. 760 pages, 1062 colour photographs, maps, tables; hard cover. [98€; received December 2013.]

Tome 3 is the first published of a new, monumental monographic treatment of the legume species of France, the publication plan of which is not stated, nor the planned number of volumes (according to external information, there will be 4 volumes in total). The included genera are 4: Ononis, Trifolium, Medicago, and
Trigonella, and the species, including aliens, almost 150 . The treatment is exhaustive, including detailed descriptions, full synonymies, identification keys (except for Trifolium, separate keys are provided for material with fruits only), completely new distribution maps for the French territory, by départements, and generous photographic illustrations, with close-up pictures of vegetative, floral and fruit details useful for identification. For the generic and infrageneric classification adopted, full use is made of recent results of molecular studies which, combined with morphological criteria, results in novel, original concepts. In particular, the sections of Medicago are redefined and a new, unispecific one is described (but not validly named) for $M$. arabica; and Melilotus is sunk in Trigonella where it forms two subgenera, resulting in 16 new combinations and 2 (illegitimate) replacement names at subgeneric, sectional and species rank. Whether or not one subscribes to these novel concepts, they make of this work a milestone in legume taxonomy that cannot be ignored.

Wilhelm BARTHLOTT, Bernadette GROSSE-VELDMANN \& Nadja KoROTKOVA - Orchid seed diversity. A scanning electron microscopy survey [Englera, $\mathbf{3 2}$ (ISSN 0170-4818)]. - Botanische Garten \& Botanisches Museum Berlin-Dahlem, Berlin, 2014 (978-3-921800-92-8). 245 pages, 620 scanning micrographs, photographs (some in colour), drawings, graphs; laminated cover. [Received December 2014.]

There exist scattered published data on and illustration of orchid seed morphology, but this is the first coherent overview for the entire family, with descrip- 
tions for 352 (40\% of the ca. 880 currently recognised) genera and scanning electron micrographs for ca. 330 of them (mostly two for each, at different, unfortunately unspecified scales). A coherent descriptive terminology is proposed, and 17 seed types are defined. The previously suspected taxonomic relevance of seed features is confirmed, especially at the tribal and subtribal level, less so at the ranks of subfamily and genus. This is borne out by plotting 15 particular characters as well as the seed types on a phylogenetic tree of the family or, in some cases, of the subfamily Epidendroideae alone.

Giorgio Perazza \& Richard LorenzLe orchidee dell'Italia nord-orientale. Atlante corologico e guida al riconoscimento. - Osiride, Rovereto, 2013 (97888-7498-192-2). 448 pages, numerous colour photographs, drawings and distribution maps; paper. [Received December 2013.]

The book brings, on one hand, the result (in the form of grid maps) of a new, thorough inventory in the field, by hundreds of enthusiast members of provincial and regional groups of orchid lovers; and on the other hand it is a guide for the easy identification of orchids by means of keys and excellent colour photographs of details, habit and habitats. Original drawings by Barbara Rauss and Lucio Sottovia, mostly of single flowers, are included. The area covered is essentially delimited by the rivers Ticino and Po to the west and south, the national border and the Adriatic Sea to the north and east. In all, 29 genera and 76 orchid species are or were present (one being extinct). Notes of their variability (two new status transfers, one newly described variety) and habitat preferences are also provided, but no formal species descriptions.

\section{Floras}

Santiago Castroviejo $\uparrow$ (gen. ed.), Enrique Rico, Manuel Benito CresPo, Alejandro Quintanar, Alberto HeRRERO \& Carlos AEDo (vol. ed.) Flora iberica. Plantas vasculares de la Península Ibérica e Islas Baleares. Vol. XX, Liliaceae-Agavaceae. - Real Jardín Botánico, Madrid, '2013' [2014] (ISBN 978-84-009745-5, volume; 978-84-0006221-7, set). L + 651 pages, map, 104 plates of drawings; cloth with dust jacket. [43 €; received February 2014.]

Includes the treatment of the "liliiflorous" monocots, i.e. the three Englerian families Liliaceae s.l. (except Smilax, already published as Smilacaceae in Vol. 21), Amaryllidaceae (not including Allium), Iridaceae, and the exotic Agavaceae. In view of the still considerable instability of the more modern, phylogenetic classification of these plants, there is a lot to be said in favour of the adopted traditional, pragmatic if admittedly unnatural family delimitation. The sequence of genera, when possible, conforms to the tenets of APG III. The species described in this volume number 224, assigned to 62 genera, of which the largest are Allium (35 species), Narcissus (25), Gagea and Asphodelus (12 each). Generic delimitations vary from extremely narrow (6 genera for Iris) to traditionally wide (Scilla, Urginea). Individual treatments of families and genera are available online as searchable pdf files, at http://www.floraiberica.es/floraiberica/ texto/pdfs $/ 000 \% 20$ clavegeneral.pdf. The next volume expected to be pub- 
Publications

lished is Vol. 9, Rhamnaceae to Polygalaceae, leaving Vol. 16 and 19, Compositae and Gramineae, for the end.

Santiago CastrovieJo $\uparrow$ (gen. ed.), Juan Antonio Devesa, Alejandro QuintaNAR, Miguel Ángel GaRCíA (vol. ed.) Flora iberica. Plantas vasculares de la Península Ibérica e Islas Baleares. Vol. XVI(I), Compositae (partim). - Real Jardín Botánico, Madrid, 2014 (ISBN 978-84-009883-4, volume; 978-84-0006221-7, set). XLVIII + 734 pages, map, 146 plates of drawings; cloth with dust jacket. [43 €; received January 2015.]

The first of three planned Compositae volumes treats the subfamily Carduoideae, which has the Mediterranean area as one of its centres of diversity. Following recent classification schemes, a single tribe is recognised, misnamed "Cynarocephalae", and the traditionally recognised tribes are reduced to subtribal level. Generic limits by and large follow the treatment in Med-Checklist, except for Carduncellus being kept separate from Carthamus and Cyanus merged under Centaurea. Of the 29 genera (209 species) included, Centaurea with its 93 Iberian species is by far the largest. Endemism is high, aliens are all but absent, and only two (safflower and artichoke) are cultivated plants. The two remaining Compositae subfamilies of the Iberian flora, Cichorioideae and Asteroideae, are left for tome 2 an 3, respectively.

Jean-Marc TIson, Philippe Jauzein \& Henri MichaUd - Flore de la France méditerranéenne continentale. - Conservatoire botanique national méditerranéen de Porquerolles \& Naturalia, Turriers, 2014 (ISBN 978-2-909717-90-6). 2078 pages, numerous drawings, 380 colour photographs on 126 plates, 2 maps in colour + caption on extra pages and cover inside; hard cover [96 €; received August 2014].

This new Flora encompasses the vascular plants of Mediterranean France, from the eastern Pyrenées to the southern Alps, to the exclusion of Corsica. The question of how best to delimit its territory had been thoroughly debated, with the result that, essentially, political boundaries were to be adopted. The declared coverage concerns two of the Régions of France: Languedoc-Roussillon in its totality (Dépts. Aude, Gard, Hérault, Lozère, Pyrénées-Orientales) and Provence-Alpes-Côte d'Azur, with 4 of its 6 Départements (Alpes-Maritimes, Bouches-du-Rhône, Var, Vaucluse). However, some bordering portions of 5 neighbour Départements (Alpes-de-Haute Provence, Ardèche, Aveyron, Drôme, Hautes-Alpes) are in effect also included, as 6 of the 20 natural regions here defined transgress the declared boundaries to the north.

This is a critical Flora, as it includes numerous and sometimes quite extensive notes. It is also an illustrated Flora, as a large majority of recognised (numbered) taxa are represented by analytical drawings. To some extent it even qualifies as a pictorial Flora; and indeed the colour photographs at the end, being limited to a selection of just 21 genera, are excellent identification aids. The plant groups thus represented are the orchids (100 photographs), Compositae (79: 69 Hieracium, 10 Tragopogon), “Liliiflorae" (75: 36 Allium, 24 Tulipa, 15 Iridaceae), Orobanche (42), Crassulaceae (39), Opuntia (15), Aristolochia (12), Pinguicula (10), and Melampyrum (6). It is a real pity that 
there is no reference to these (unnumbered) photographs in the main text, nor even in the index: one has to know or to guess, or one will miss them.

Floras arranged according to the last cry of phylogenetic systematics are still the exception (fortunately so, many will feel), and the present one is among these exceptions. Not for long, I dare say, as with the current rate of change in vascular plant classification the currently recommended one will soon be almost as out of date as the old Englerian system, and more quickly forgotten. Within families, genera and species are also arranged by known or perceived affinity, with the single exception of Umbelliferae where the sequence is alphabetical. The umbels, which happen to be the last family in the APG linear arrangement, are also unique in two other respects: they are the single family that was not authored or at least co-authored by either Tison or Jauzein, and the only one in which due credit is given to the author or source of the drawings. Otherwise, and this is the single real criticism I am bound to make, the illustrations are anonymous, unless the subtitle on p. 9 be taken to infer that the text authors have also drawn the figures (an unlikely assumption in view of the diversity of styles).

The treatment of notoriously difficult groups, one of the standards by which to judge "critical" Floras, varies widely. For example, Rosa and Rubus are dealt with rather summarily, with very broadly delimited species, or for some of the brambles down to subsectional level only; whereas Hieracium and Taraxacum have received full and remarkably skilled attention. Their accounts will stand as models far beyond the limited geographical range for which they were written.

All in all, this Flora stands as a milestone in French botany. Its authors deserve our gratitude and admiration for a huge amount of work well done. When writing these lines I had not yet seen the new Flora gallica, of which Tison is also the first author. It will doubtless expand the concepts of the present work to the whole territory of France, if with lesser detail of descriptive and distributional data. Which means that the year 2014 marks the onset of an entirely new era for plant diversity studies in France.

Daniel Jeanmonod \& Jacques GaMISANS - Flora corsica, $2^{\text {ème }}$ édition. [Bulletin de la Société Botanique du CentreOuest, Numéro spécial (ISSN 0759934x), 39.] - Société Botanique du Centre-Ouest, Jarnac, 2013. 1074 pages, 134 plates of drawings, 3 maps, 2 vegetation profiles, tables; plastic cover. [55 €; received fall 2013.]

This second edition follows the first (see OPTIMA Newslett. 38: (18-19). 2008) after only 6 years. Citing from the initial review: "The wild flora of Corsica comprises almost 2400 species, including casual $(10.5 \%)$ and naturalised $(6,4 \%)$ aliens. Endemism is considerable, the 146 strictly endemic taxa corresponding to $6,3 \%$ of the indigenous flora. The new tenets of molecular-based phylogeny have been followed with respect to family sequence: three 'basal' families (Nymphaeaceae, Lauraceae, Aristolochiaceae) precede the monocots, followed in turn by the dicots starting with Ceratophyllum. Family delimitations have been kept as is traditional, 
Publications

with deviating modern alternatives (the Angiosperm Phylogeny Group's APG II family concepts) mentioned in brackets, subtitles or notes." In the latter aspects the second edition does not deviate seriously from its predecessor, except that reference is now made to the still newer APG III family concepts. Generic limits, however, and by consequence species nomenclature, were modified in a number of cases. The figure for species has slightly increased (to 2411), reflecting the addition of 25 additional units, not quite balanced by the loss of several Hieracium taxa consequent to the thorough revision of that genus by JeanMarc Tison. That loss also explains the lowering of the rate of insular endemism to $5.9 \%$.

Pier Virgilio ARRIGonI - Flora dell'isola di Sardegna, 4. - Delfino, Sassari, 2013 (ISBN 978-88-7138-677-5). Pages [5]-584, 232 plates of drawings or in facsimile; hard cover. [Received fall 2013].

Previous volumes of this new, basic Flora for the island of Sardinia - which won its author the OPTIMA Silver Medal for the year 2006 - have been presented in detail earlier (see OPTIMA Newslett. 38: (19-20). 2008; 40: (7-8). 2011). Volume 4 comprises the treatments of the families Umbelliferae (the last dialypetalous one still missing, and the largest in bulk) to Rubiaceae inclusive, among which Labiatae and Scrophulariaceae (traditionally circumscribed) are prominent. This leaves Compositae and the monocots for the remaining 2 (or 3?) volumes. As previously, the treatments of genera and species are full, critical, and sometimes innovative. The illustration is generous and of excellent quality, most being original drawings by Anne Maury (signed AM) and B. Buonarroti (BB), others reproduced from published sources and mostly initialled by Ignazio Camarda and Franca Valsecchi, yet others being facsimiles of the masterly plates in Moris's Flora sardoa.

Vladimir Stevanović (ed.) - Flora Srbije, 2. - Srpska Akademija Nauka i Umetnosti, Beograd, 2012. XIV + 619 pages, 66 plates of drawings, 142 maps; hard cover. [Received fall 2013].

Volume 2 of what is basically the $2^{\text {nd }}$ edition of Josifović's well known Flora SR Srbije follows vol. 1 (see OPTIMA Newslett. 30: (12). 1996) after an interval of no less than 20 years. It comprises treatments of the orders Ran[uncul]ales (p.p.: Berberidaceae), Papaverales, Hamamelidales, Urticales, Fagales, Betulales, Juglandales, and Caryophyllales, with Caryophyllaceae as the by far largest family. The Serbian distribution of species, except the widespread ones, is now mapped individually. Hopefully, publication progress will henceforth speed up under a changed editorship.

Mohamed Fennane, Mohammed IbN TAtTou \& Jalal El-Oualidi (ed.) Flore pratique du Maroc. Manuel de détermination des plantes vasculaires. Volume 3, Dicotyledones (p.p.), Monocotyledones [Travaux de l'Institut Scientifique, Série Botanique (ISSN 11141174), 40.] - Institut Scientifique, Université Mohammed V, Agdal, Rabat, 2014 (ISBN 978-9954-20-671-3). XI + $793+[1]$ pages, map, 93 plates of drawings +99 figures; cloth with dustcover.

To date, Morocco was the last among the countries bordering the Mediterra- 
nean Sea to lack a completed descriptive manual of its flora, a work permitting, by means of descriptions and keys, the identification of its plants. Now the circle has been closed. The present volume is the last missing link among Mediterranean Floras. Its publication is an event well worth being celebrated!

The two first volumes (see OPTIMA Newsletter 38: (16). 2008) were published in 1999 and 2007 as volumes 36 and 38 of the same prestigious monograph series of the Institut Scientifique in Rabat, better known by its former attribute Chérifien. The present, concluding volume encompasses the treatments of the last dicot families (Rubiaceae to Compositae) and of all monocots. The family key and illustrated glossary are again included, and there is a cumulative index of genera for all volumes. The presentation is elegant yet concise, avoiding details such as nomenclatural source and type citations that would be of scant interest for the botanical practitioner.

The work as a whole is the essential instrument required for the formation of a new generation of keen Moroccan botanists. It must not be seen as a concluding event but as the door to ongoing studies leading, in a not too remote future, to an even better understanding and fuller knowledge of the extraordinary riches and variety of the vascular plants of Morocco.

\section{Popular Books}

Peter SCHÖNFELDER \& Ingrid SCHÖNFELDER - Was blüht am Mittelmeer? [ed. 5] - Kosmos, Stuttgart, 2014 (ISBN 978-3-440-13742-0). 320 pages, 875 colour photographs, 286 maps, illustrated on inside cover and cover flaps; plastified cover. [Ca. $17 €$; received May 2014].

Peter SCHÖNFELDER \& Ingrid SCHÖNFELDER - Flora del Mediterraneo. Ricca, Roma, 2014 (ISBN 978-88-6694020-3). 320 pages, 875 colour photographs, 286 maps, illustrated on inside cover and cover flaps; plastified cover. [29 €; received September 2014].

This pocket guide to the common and characteristic representatives of the Mediterranean flora has undergone substantial change since its first edition in the Kosmos Naturführer series (1987), and even more so since its precursor, "Das blüht am Mittelmeer" (Bunte Kosmos Taschenführer, 1975), with its mere 120 photographs. The current, fifth edition has been modernised in presentation and improved in contents. For each of the 286 species treated in full a map showing the area-by-area distribution is provided, using the Med-Checklist territories as a base but with addition of the Canary Islands. Under most entries, a second species is illustrated and briefly commented upon, under the heading "Weitere Art". It is slightly confusing, even though duly explained in the preface, that the map does not correspond to the species shown immediately below, in the same frame, but to the one that is illustrated on the opposite page. Needless to say, the photographs, taken by a botanist and master of the art, are not only beautiful and technically perfect but also illustrative of the characteristic traits of the plant. As a first, the book is available in parallel editions in Italian (see above), French and Croatian (not 
Publications

seen), which in an OPTIMA perspective is particularly welcome news.

Voislav VASIĆ \& Marina ILIĆ - Belgrade through nature and time. Guide through bio-geo-diversity of Belgrade. Association "School for Survival", Beograd, 2012 (ISBN 978-86-914123-5-7). 108 pages, colour photographs, maps, table; paper. [Received fall 2013].

A guide and companion, through Belgrade and its immediate surroundings, for the hiker with naturalistic interests. It illustrates and comments monuments and geological features, gardens, parks and individual trees, as well as representative plants, fungi and animals, strung up along suggested itineraries where one can meet them. The acknowledged, commendable purpose is to acquaint visitors of all ages with the principal aspects of biological and geological diversity in a very attractive urban area.

\section{Floristic Inventories and Checklists}

Alain Dobignard \& Cyrille ChateLAIN - Index synonymique de la flore d'Afrique du Nord. Volume 5 Dicotyledoneae, Oleaceae à Zygophyllaceae. [Publication hors-série $\mathrm{N}^{\circ}$ 11d.] Conservatoire et Jardin botaniques, Genève, 2011 (ISBN 978-2-8277-0128-5). 451 pages, tables, map; laminated cover. [Received fall 2013].

The concluding volume of the work, for which the authors have been awarded OPTIMA's Silver Medal at the Organisation's recent Meeting in Palermo, September 2013. The previous volumes have been reviewed in OPTIMA Newslett. 40: (12-14). 2011 and 41: (11-12). 2013. To quote from the first review: "Doubtless one of the most important works in Mediterranean plant science published in recent years. A synthesis based on the first author's experience of a lifetime with North African plants and on an extensive survey of old and recent literature, the Index raises our knowledge of the flora of that area to the level at which Med-Checklist has been aspiring". The Index covers the countries of $\mathrm{N}$ Africa bordering the Mediterranean Sea plus Madeira, the Canary Islands and (partly) some southern bordering areas. As in previous volumes, There are critical notes by various authors at the end, plus updates to the four previous volumes, in which new country records are documented and several nomenclatural novelties presented (genera: Centranthus, Colchicum, Danthonia, Pallenis, Polygonum, Potentilla, Ranunculus, Saxifraga, Taraxacum, Verbascum, Veronica). The number of accepted vascular plant species listed for the area in all five volumes reaches an impressive total of 7860 (9098 different taxa).

Panayotis Dimopoulos, Thomas Raus, Erwin BergMeIER, Theophanis CONSTANTINIDIS, Gregoris IATROU, Stella KoKKINI, Arne STRID \& Dimitrios TSANOUDAKIS - Vascular plants of Greece. An annotated checklist. [Englera (ISSN 0170-4818), 31.] Botanischer Garten \& Botanisches Museum Berlin-Dahlem \& Hellenic Botanical Society, Berlin \& Athens, 2013 (ISBN 978-3-921800-88-1). 372 pages, tables, maps, graphs, figures, 24 plates of colour photographs; hard cover. [42 €; received November 2013].

This is the first inventory ever of the vascular flora of Greece in its present political boundaries. In its core portion, 6600 taxa (species and subspecies) oc- 
curring in Greece in the native or naturalised state are listed in tabular form, each with within-country distribution by 13 regions and indication of status, chorology and life form categories. Other important chapters (or appendices) list synonyms (including misapplications) and critical notes on individual taxa. Literature has been covered very thoroughly and the information critically assessed. The book is therefore a remarkably reliable while easy-to-use source of information. At the end, colour photographs, mostly by Arne Strid, show 216 of the species, including many extremely rare and seldom encountered ones.

Siegmar-W. Breckle, Ian C. Hedge \& M. Daud RAFIQPOOR - Vascular plants of Afghanistan, an augmented checklist. - Scientia Bonnensis, Bonn, Manama, New York \& Florianópolis, 2013 (ISBN 978-3-940766-64-9). 598 pages, numerous maps and colour photographs, graphs, tables, 1 sheet of Corrigenda; hard cover. [Received January 2014].

This book, aptly dedicated to Karl Heinz Rechinger and his widow Wilhelmina, is a companion volume to Breckle \& Rafiqpoor's "Field Guide Afghanistan" of 2010 (see OPTIMA Newslett. 40: (17). 2011). The introductory and general parts are again bilingual (English and Tari), with the two versions side by side in parallel columns; but this time the pagination runs front to back, not the other way round as is the Arab custom. The general chapters were partly rewritten and much shortened, mainly at the expense of subjects such as physical geography and general notions of systematic botany, that had been mainly designed for use by Afghan students. The core is a complete checklist of the Afghan vascular flora, in tabular form, comprising accepted names and main synonyms (with citation of nomenclatural source); Afghan distribution by provinces (as small maps); general distribution; altitudinal range; and Notes (including references to the "Field Guide", when applicable). Families, genera and species are arranged alphabetically within the 4 main groups, pteridophytes, gymnosperms, dicots and monocots. The checklist was produced independently of, and often deviates from, Dieter Podlech's recent (2012) Afghan checklist available online, which furthermore lacks vascular cryptogams (see http://www.sysbot.biologie.uni-muenchen. de/de/personen/podlech/flowering_plants_ afghanistan.pdf).

\section{Regional Studies}

Gerald Parolly, Kathrin Grotz \& Hans Walter LACK (ed.) - Kaukasus. Pflanzenvielfalt zwischen Schwarzem und Kaspischem Meer. Caucasus. Plant diversity between the Black and Caspian Seas. - Botanischer Garten und Botanisches Museum Berlin-Dahlem, Berlin, 2014 (ISBN 978-3-921800-90-4). 232 pages, numerous illustrations (prevalently colour photographs); laminated cover. [14€; Received May 2013].

The Caucasus Plant Diversity Initiative, launched in 2009, is a joint endeavour of the Berlin-Dahlem Botanic Garden and Museum with the leading academic institutions of the Transcaucasian countries, funded to a large extent by the Volkswagen Foundation. One of its outcomes, an important forum for the public presentation of its results, is an exhibi- 
Publications

tion that has been prepared at the renowned Berlin-Dahlem institution, which opened in May 2014 and is to last one year. The present, fully bilingual volume is divided into two halves, the second being an explanatory guide to the exhibition proper. The first half consists of a number of fluently written and informative essays on various topics related to (Trans-)Caucasian botany, by a large number of authors from all of the participating centres. Some present focal studies on particular families and genera (pears, bluebells and the relict tree Zelko$v a$ ), others are of historical interest (in particular, Walter Lack's masterly synthesis of the countries' botanical exploration); several expand on the themes of conservation and sustainable use, through ecotourism in particular; cultural, including culinary and horticultural aspects feature prominently, with chapters on winemaking, saffron and pomegranate lore.

\section{Studies of Flora and Vegetation}

Sonja Coneva, Valeri Georgiev, Vladimir Vălev \& Anna Ganeva - Atlas vodni i vodoljubivi rastenija $v$ Bălgarija [Atlas of aquatic and wetland plants of Bulgaria]. - Institut po Bioraznoobrazie i Ekosistemni Izsledvanija pri Bălgarska Akademija na Naukite, Sofija, 2012 (ISBN 978-954-9746-28-0). 200 pages, prevalently of colour photographs; hard boards with ring binding. [Received fall 2013].

A splendid photographic atlas, depicting $150+$ species of vascular plants and $13+$ bryophytes out of the total of 345 recorded Bulgarian hydrophytes and hydrophilous plants. Concise texts provide relevant information for every species (or genus). For several critical groups (e.g. Callitriche, Carex, Cyperus, Persicaria, Juncus), juxtaposed photographs allow ready comparison and easy identification. As most of the illustrated species are widespread, the book, which has an English summary, is likely to prove useful to botanists throughout the Mediterranean area.

\section{Chorology}

Arto Kurtto, Alexander N. SenNiKov \& Raino LAMPINEN - Atlas florae europaeae. Distribution of vascular plants in Europe, 16, Rosaceae (Cydonia to Prunus, excl. Sorbus). - Committee for Mapping the Flora of Europe \& Societas Botanica Fennica Vanamo, Helsinki, 2013 (ISBN 978-951-9108-17-9). 168 pages, maps, tables and graphs; paper. [Received January 2014].

This ought to have been the final Rosaceae volume; but there will be one more for Sorbus alone, "which has recently experienced a renaissance of interest". Of the 170 distribution maps, numbered 4709 to 4898,30 relate to each Crataegus and Prunus (sensu lato, being the single genus recognised in Amygdaloideae), and no less than 73 to Cotoneaster. Species inflation in the latter is largely due to Britain, where the genus is not native but numerous ornamentals are reported as naturalised. Generic limits have been kept stable in the traditional way, inclusion of Mespilus in Crataegus being the single exception.

\section{Excursions}

Ina DiNTer (ed.) - Türkei. Botanische Exkursion 2013. Institut für Botanik, Universität Hohenheim, Stuttgart. 3.-17. März 2013. - Universität Hohenheim, 
Stuttgart, 2013 (ISBN 978-3-00-043497$6) . V+133$ pages, maps, figures, colour photographs, tables; paper. [Received November 2013].

Ina DinTer (ed.) - Türkei. Botanische Exkursion 2014. Institut für Botanik, Universität Hohenheeim, Stuttgart. 20.30. März 2014. - Universität Hohenheim, Stuttgart, 2014 (ISBN 978-3-00-047553$5)$. VI +130 pages, maps, graphs, colour photographs, tables; paper. [Received November 2014].

Ina DINTER - Pyrenäen und Ebrodelta (Spanien). Botanisch-Ornithologische Studienreise vom 17. - 28. Juni 2013. Privately assembled/printed, Ostfildern, 2013. 57 pages + CD-ROM, maps, figures, colour photographs, tables; paper, plastic front cover sheet. [Received November 2013].

Ina DINTER - Südanatolien (Türkei). Botanische Studienreise vom 1. - 15. April 2014. Exkursionsbericht. - Privately assembled/printed, Ostfildern, 2014. $\mathrm{V}+80$ pages $+\mathrm{CD}-\mathrm{ROM}$, maps, graphs, colour photographs, tables; paper, plastic front cover sheet. [Received November 2014].

For the general scheme and layout of Ina Dinter's excursion accounts, see e.g. OPTIMA Newslett. 41: (15-16). 2013. The two first of the above items deviate from the usual standard. They relate to university excursions to SW Anatolia and are formal publications, rather than the customary privately published accounts. They are partly based on the students' own records taken on the spot, and the field identifications listed are sometimes supported by photographs but not by vouchers (perhaps a result of Turkey's new, very restrictive regula- tions on biological collecting). The third and fourth item relate to excursions of the traditional type, to the Central Pyrenees of Aragón plus the Ebro delta and to Lycia, respectively (again, neither mentions vouchers). Even though the Spanish trip was part ornithological, botany clearly predominates in both accounts, and also in the complementary documentation on CD-ROM. For Lycia the latter, same as for previous excursions, comprises a rich harvest of plant and landscape photographs; but not for Spain, where the CD is entirely devoted to reproductions of relevant literature.

\section{Applied Botany}

Ana Petrova, Vladimir Vladimirov \& Valeri GEORGIEV - Invasive alien species of vascular plants in Bulgaria. - Institute of Biodiversity and Ecosystem Research, Bulgarian Academy of Sciences, Sofija, 2013 (ISBN 978-9549746-30-3). 320 pages, numerous colour photographs, c. 60 distribution maps; hard cover. [Received fall 2013].

Following general, introductory background information, 60 selected species judged to be invasive or threatening to become so are presented in alphabetical sequence. Excellent colour photographs (mostly by Vlado Vladimirov), representing both the general habit and habitat and analytical details in close-up, permit to recognise each species with confidence. Details of the introduction and spread are provided when available. Grid maps visualise the current distribution in Bulgaria, in which only the red dots stand for documented occurrences (blue dots denote the potential area of widespread but seldom collected weeds). Remarkably, there appears to be not a 
Publications

single documented locality of that widespread archaeophyte, Erigeron canadensis!

Neriman Özhatay, Mine KoçiĞít \& Mehmet BoNA - İstanbul'un ballı bitkileri "Çiçek varsa bal var". - Bal-der Bee Products, [Istanbul, 2010?] (ISBN 978-605-86798-2-5). 264 pages, numerous colour photographs, SEM micrographs, maps, graphs, table; hard cover. [Received fall 2013].

A picture book and manual for the melliferous plants of the Istanbul area, with Turkish text throughout. After introductory chapters, the main portion illustrates 150 (mainly) herbaceous species, grouped by flower colour, and 18 woody plants, each with one or more excellent colour photographs (by Adil Önder Erdem), a scanning micrograph of the pollen, and a map showing its distribution in the Istanbul area. Thirteen cultivated honey-yielding plants form an appendix.

Diego Rivera, Gonzalo MAtilla, Concepción OBón \& Francisco ALCARAZ - Plants and humans in the Near East and the Caucasus. Ancient and traditional uses of plants as food and medicine. An ethnobotanical diachronic review. Volume 1. The landscapes. The plants: ferns and gymnosperms. Volume 2. The plants: angiosperms. - Servicio de publicaciones, Universidad de Murcia, Murcia, 2012 (ISBN 978-84-15463-078, whole work; 978-84-15463-05-4, vol. 1; 978-84-15463-06-1, vol. 2). $341+$ 1057 pages, tables, graphs, maps; plastified flexible cover. [Received fall 2013].

The work focuses on, and bridges, the interface between man and plants for a huge territory, coinciding approximately with the domain of Boissier's Flora ori- entalis bar Greece and Egypt, even though for some aspects geographical coverage may be more limited. The introductory portion deals with aspects of the physical geography, flora, vegetation and phytogeography on one hand, human settlement and archaeology on the other. In the main portion, the treatment is by families, genera and species. It is an exhaustive compendium of data on plants with their traditional uses, encompassing any and all aspects of interest to man, throughout historical times. The data derive from an impressive number and variety of published texts, including the writings of antiquity and archaeobotanical literature (listed for both volumes at the end of vol 1). It is not always clear how the botanical identity of the plants concerned has been established, particularly when important basic Floras such as Rechinger's Flora iranica and inventories like Heller's Compendium florae orientalis have not or scarcely been consulted. Usefulness of the books would have been greatly enhanced by running titles mentioning family and genus, and by the presence of indexes.

\section{Conservation Topics}

Andrew Byfield, Sema Atay \& Neriman ÖZHATAY - Important plant areas in Turkey: 122 key Turkish botanical sites. - WWF Turkey, İstanbul, 2010 (ISBN 978-605-60247-9-5). 463 pages, colour photographs and maps, tables; paper. [Received fall 2013].

The 122 current Important Plant Areas of Turkey were defined in 2003 (see OPTIMA Newslett. 37: 90-91. 2004). In that initial presentation each could be but briefly characterised, but three years 
later Neriman Özhatay a published a book in which a selection of 22 of them were described and illustrated more fully (see OPTIMA Newslett. 38: (60). 2008). The present volume now gives a thorough, generously illustrated account of all 122 Turkish APIs, with their extension mapped and with lists, for each, of those species present that are of global or European conservation concern. The consolidated inventory of these 3056 taxa is included in Appendix II, whereas Appendix III brings accounts of 87 threatened endemic species of major concern. The alphabetic index to the subjects of the almost 400 colour photographs is a useful complementary feature of the book.

Florian Mombrial, Beat BÄUMLER, Philippe Clerc, Christine Habashi, Hélène Hinden, Catherine LAMBELETHaueter, Pascal Martin, Michelle Price \& Raoul PALese - Flore en ville. Sites et espèces d'intérêt en Ville de Genève. [Publication hors-série $\mathrm{n}^{\circ}$ 15.] - Conservatoire et Jardin botaniques de la Ville, Genève, 2013 (ISBN 978-28277-0130-8). 276 pages, photographs, graphs, maps, tables, all in colour; laminated cover. [Received December 2014].

Essentially this is a description of 22 urban priority sites, defined for conservation purposes on the basis of the presence of priority plant species; as well as a characterisation of the priority species themselves. It rests on thorough inventories, 2011 to 2013, of vascular plants, bryophytes and lichens present in each site. On a total surface area of merely 46 ha 771 species are recorded: 437 vascular plants $(57 \%), 149$ bryophytes (19\%), and 185 lichens (24\%). The full documentation of the two latter groups, often bypassed in this kind of studies, adds considerably to the interest of this well presented, superbly illustrated compendium, which also serves to document the dynamics of change undergone by urban areas: In 2011, at the onset of this study, 23 priority sites had been defined; at the end, 4 had been added and 5 deleted, partly because they had meanwhile been destroyed or had lost their priority species, partly because the latter's alleged presence rested on misidentification.

\section{Gardens and Gardening}

Gideon F. SMith \& Estrela FigueIREDO - Succulent paradise. Twelve great gardens of the world. - Struyk Lifestyle, Cape Town, 2013 (ISBN 978-143170090-5). 184 pages, numerous colour photographs; paper. [Received December 2014].

The book is a round-trip to a selection of twelve botanic gardens specialised in the growing of succulent plants, or having a large section thus specialised. They are scattered over three continents (Africa, Europe, North America) and seven countries: South Africa (2), France (2), Monaco, Italy, Switzerland, the USA (4), and Mexico. None is among the great, universally known institutions of their kind; rather, they are small gardens of mostly recent origin, familiar mainly to insiders, often founded by privateers and some still privately owned. With a single exception (the City of Zürich's Succulent Plant Collection) they are situated in climates in which succulents can be freely grown out of doors - half of them in Mediterranean-type climate zones. An instructive and beautiful book, full of surprises and novel perspectives. 
Publications

Mariachiara Pozzana. - The gardens of Florence and Tuscany. Complete guide. - Giunti, Milano, 2011 (ISBN 978-88-09-75952-7). 191 pages, numerous colour photographs, drawings, maps; laminated cover with flaps. [14.90€; Received 27 Feb 2015].

This is the ultimate guide to Tuscany's gardens. It describes and colourfully illustrates 9 gardens within the city of Florence, 15 in the surroundings and 37 elsewhere in the region: a glorious total of 61 , each with details of access, opening hours and fees. Not counted in the total are 34 gardens judged to be of lesser importance or interest and only briefly mentioned, among them the Botanical Gardens of Pisa and Lucca! If you want to visit even a good selection only, which is certainly worth your while, plan well ahead, take your time, and choose a good season.

\section{Bibliography and Biography}

Stefan Stanev - Părvostroiteli na Bălgarskata botanika. Malko poznati imena ot Bălgarskata botanika. - Universitetsko izdatelstvo "Paisij Hilendarski”, Plovdiv, 2015 (ISBN 978-619-202022-4). 617 pages, black-and-white photographs (portraits); hardcover. [Received Mar 2015].

As the title suggests, this is two books in one, continuously paginated. The first half (pp. [3]-326) is devoted to the "Founders of Bulgarian botany", the second (pp. 327-615) to "Little known names in. Bulgarian botany". Both consist of extensive biographical sketches, with mention of new discoveries (including newly named taxa), distinctions received (such as taxa named after each), lists of publications, and relevant bibliographic sources. In the first half, the main protagonists of Bulgarian botany are treated - not all of them Bulgarian nationals: Frivaldsky, Janka; Pančić, Velenovský, Georgiev, Petkov, Urumov, Davidov, Bubak, Adamović, Arnaudov, Stojanov, Stefanov, Achtarov, Jordanov, Christov, and Kitanov. The 30 botanists of the second half, while obviously less well known, are also less documented in literature and therefore of particular interest. Both halves are in fact second editions, as is obvious from the preface matter but not mentioned in the impressum: the "Founders" volume was first published in Plovdiv, by the same editor, in 2008; the "Little known names" one in Sofia, by Pensoft, in 2001.

Francesco Maria RAIMONDo - Contributi alla promozione della cultura botanica. A cura di Franco PedRotTI. [Collana Natura e Aree Protette, 29.] Temi, Trento, 2015 (ISBN 978-8897372-83-7). 245 pages, facsimiles in colour; paper with cover flaps. [15€; Received 26 Feb 2015].

Presented to Raimondo at a symposium in Florence commemorating his recent 70th birthday, this book is a rather unusual kind of festschrift, having been written entirely by the birthday boy himself. It is also unprecedented in its contents. It is a (not quite complete) compendium of introductions to books and in some cases almanacs as well as laudations written by Raimondo. An excellent idea, is it not? One worthy of being copied. But then, how many persons, botanists in particular, do you know to have published over 100 such items - enough to fill a sizeable volume - as did Raimondo over a period of just 25 years 
(starting in 1990, the last being dated 15 January 2015)? The 105 texts included (but unfortunately not indexed), embellished by the colourful facsimiles of the front covers of the respective publications, cover a vast range of topics, from purely botanical, even nomenclatural, to historical, biographic, geographical, pictorial and generally cultural, reflecting Raimondo's broad sphere of skills and interests. The title was aptly chosen by the editor Pedrotti, who also invented the whole idea. It expresses the fact that by this kind of contributions, which many may consider marginal and are indeed a mere by-product of a prolific botanical career, Raimondo has certainly done much to promote botanical culture in general.

Elena Macellari - Botaniche italiane, scienziate naturaliste appassionate. [Collana Natura e Aree Protette, 28.] Temi, Trento, 2015 (ISBN 978-8897372-80-6). 233 pages, ca. 150 illustrations in colour or black-and-white; paper with cover flaps. [20 €; Received 26 Feb 2015].

This anthology of nine full and a dozen short biographies of women who, some overtly and prominently but many by discreet and modest work, have taken influence on the development of botany in Italy is not one of the too many books written in vindictive feminist style but a dispassionate display of how persons of female sex, while operating within the often constraining social and cultural environment of their time, managed to promote scientific knowledge in their discipline. You will find well-known figureheads among them, such as Eleonora Francini Corti, Daria Bertolani Marchetti and Carmela Cortini Pedrotti, each with a distinguished publication record in her respective specialty and an often prominent academic career; but several other you have hardly ever heard of and whose name, in some cases, has been newly unearthed here for the botanical sciences. The book is written is a well readable, very personal style testifying to the personal involvement of its author, herself a member of the fair sex with botanical interests, in the persons and circumstances she describes.

Kristin VICTOR (ed.) - Carl Haussknecht. Ein Leben für die Botanik [Beiträge aus den Sammlungen der Universität Jena, 2.]. - Friedrich-SchillerUniversität, Jena, 2013 (ISBN 978-3-00044408-1). 111 pages, photographs (mostly in colour), facsimiles, maps; paper. [Received November 2013].

A Festband produced as a corollary and guide booklet for an exhibit to commemorate the well known botanist and founder of the Haussknecht Herbarium, Carl Haussknecht (1838-1903). Many original documents of botanical interest are reproduced, including portraits of contemporary botanists, mapped itineraries of Haussknechts SW Asian collecting expeditions, and herbarium specimens. There is an updated bibliography of Haussknecht's publications (by $\mathrm{H}$ : Manitz), a list of names of plants (plus one land snail) commemorating Haussknecht, and accounts of his collections - not only herbarium and library: antiquities and coins, too, formed part of his range of interest. A treasure trove for all interested in $19^{\text {th }}$ Century travelling and in the botanical and geographical exploration of SW Asia.

Guido Moggi - Frammenti di memoria. Spigolature botaniche: personaggi, 
Publications

collezioni, storie. - Polistampa, Firenze, 2013 (ISBN 978-88-596-1276-6). 157 pages, richly illustrated (photographs, drawings, graphs, facsimiles, maps, tables), mostly in colour; paper. [Received fall 2013].

Illustrated text of 11 lectures presented by the author at various conferences and meetings between 1978 and 2008, but so far unpublished. The range of subjects is broad: biographical (A. Lunardi, R. E. G. Pichi Sermolli), museological and historical (Museum Minà Palumbo, Gallipoli museum and library, Palermo Botanic Garden, acclimatization gardens in Tuscany, pre-Linnean plant systematics), particular plants (palms, saffron, common oak) - and where to place a subject such as the use of islets as penal colonies and its influence on their flora? A wealth of diverse information, to which the access is somewhat facilitated by good indexes (plant and personal names). At the end there is Moggi's succinct curriculum vitae and a list of his publications.

Per Magnus Jørgensen - Under magnoliaen. Plantminner. - John Grieg, Bergen, 2013 (ISBN 978-82-533-03017). 167 pages, photographs (mostly colour), drawings, facsimiles; paper. [Received fall 2013].

Assembles the author's and eminent lichenologist's botanical (mostly nonlichenological) reminiscences, conceived as his last report presented when retiring from his academic career.

\section{History and Arts}

Stefan Stanev \& Ana Petrova - Istorija na bălgarskata botanika $v$ dati. - Universitetsko izdatelstvo "Paisij Hi- lendarski”, Plovdiv, 2014 (ISBN 978954-423-928-2). 193 pages, black-andwhite photographs (portraits, group photographs) and facsimiles; paper. [Received Mar 2015].

The titles translates "History of Bulgarian botany in dates". Botanically relevant events related to Bulgaria are enumerated in a year-by-year sequence, starting 1774 with Italian diplomat Domenico Sestini's visit and spanning to 2013. Among others, deaths, conferences, and book publications are put on record, with a list of relevant sources as an extra bonus. The book is not easy to consult, even for the Bulgarian speaking, owing to the lack of indexes.

Laura TAllandini (ed.) - Arte botanica in Italia oggi. Botanical art in Italy today. - Edizioni ETS, Pisa, 2013 (ISBN 978-884673768-7). 87 pages, with 9 pages of black-and-white and 31 of colour illustrations; paper with cover flaps. [14 €; Received 27 Feb 2015].

The booklet, prepared as a guide to the homonymous exhibition at the Padova Botanic Garden in October-November 2013, comprises four bilingual (Italian and English) texts and a colourful ample of the artworks on exhibit. Two of the chapters are devoted to the garden's history, from its foundation in 1545 as the earliest such institution still in existence today to its restoration and enlargement, achieved in 2013 as a consequence of the Garden's inclusion in UNESCO's World Heritage List in 1997. The two remaining chapters are on botanical illustration and are largely based on the invaluable holdings of the Garden's library. The title, thus, does not really justice to the varied and interesting contents of the book. 
Gabriele Galasso \& Enrico BANFI Flora dipinta. Elementi botanici nell'arte di Bernardino Luini [Natura (Milano), 104(2), ISSN 0369-6243]. Società Italiana di Scienze Naturali \& Museo Civico di Storia Naturale, Milano, 2014. 152 pages, numerous photographs and facsimiles in colour; laminated cover. [Received January 2015].

An exhibition devoted to the works of Renaissance painter Bernardino Luini (1481-1532), contemporary of Leonardo da Vinci, was shown in spring and summer 2014 in the Palazzo Reale of Milan. It prompted the publication of the present book: an interpretation of the plants shown on a selection of 14 of Luini's remarkably naturalistic paintings. In the first portion of the volume, the painting themselves and botanically relevant portions of them are shown; the second portion presents the 43 species identified, both alive and in botanical illustrations, especially the $16^{\text {th }}$ Century books of Fuchs and Mattioli and an $18^{\text {th }}$ Century manuscript of Giambattista Morandi.

\section{Names and Nomenclature}

John H. WiERSEMA, John McNeiLl, Nick J. Turland, Fred R. BARRIE, William R. BUCK, Vincent DEMOULIN, Werner Greuter, David L. HAWKSWORTh, Patrick S. Herendeen, Sandy KNAPP, Karol MARHOLD, Jefferson Prado, Willem F. Prud'homme Van REINE \& Gideon F. SMITH - International Code of Nomenclature for algae, fungi, and plants (Melbourne Code) adopted by the Eighteenth International Botanical Congress, Melbourne, Australia, July 2011. Appendices II-VIII. [Regnum Veg. (ISSN 0080-0694), 157.]
- Koeltz Scientific Books, Königstein, 2015 (ISBN 978-3-87429-480-5). xix + 492 pages; hard cover.

More than two years after the main body of the ICN (see OPTIMA Newslett. 41: (22-23). 2013) and with more than twice its bulk, the Appendices traditionally forming part of it have at last been published. The Nomenclature Section of the Melbourne Congress had authorised this dissociation, wisely as it now appears. Not only would joint publication have resulted in too heavy and cumbersome a volume, it would also have delayed substantially the availability of the rules themselves. During the editing process, John Wiersema incorporated the contents of the Appendices in a database that also encompasses Dan Nicolson's famous "Proposals and Disposals" dataset providing insight into the historical background of each current entry. The result of Wiersema's effort is an extremely useful, online searchable information system (http://botany.si.edu/references/codes /props/index.cfm), which hopefully will henceforth be kept up to date. It is unlikely that hard-copy production of the Appendices can be maintained in the future, as every new edition will soon become outdated with respect to the online version.

Carlos E. de M. BICUdo \& Jefferson PRADo (transl.) - Código Internacional de Nomenclatura para algas, fungos $y$ plantas (Código de Melbourne), adotado pelo XVIII Congresso Internacional de Botânica, Melbourne, Austrália, Julho de 2011. Preparado e editado por J. MCNeILl, Coordenador, F. R. BARRIE, W. R. Buck, V. Demoulin, W. Greuter, D. L. Hawksworth, P. S. HERENDEEN, S. KNAPP, K. MARHOLD, J. 
Publications

Prado, W. F. Prud'homme Van Reine, G. F. Smith, J. H. Wiersema, Membros, N. J. TuRLAND, Secretário del Comitê Editorial. - Instituto de Botânica, São Paulo, 2013 (ISBN 978-85-7656-290-0). XXXIV + 208 pages; paper. [Received fall 2013].

Werner Greuter \& Pietro Mazzola (transl.) - Codice Internazionale di Nomenclatura per alghe, funghi e piante (Codice di Melbourne), adottato dal Diciottesimo Congresso Internazionale di Botanica, Melbourne, Australia, luglio 2011. Preparato e edito da J. McNeILl, Presidente, F. R. BARrie, W. R. Buck, V. Demoulin, W. Greuter, D. L. Hawksworth, P. S. HerendeEn, S. Knapp, K. Marhold, J. Prado, W. F. PRUd'hOMME VAN REINE, G. F. SMith, J. H. Wiersema, Membri, e N. J. Turland, Segretario del Comitato Editoriale. [Informatiore Botanico Italiano (ISSN 0020-0697), volume fuori serie]. - Società Botanica Italiana \& Fondatione Internazionale Pro Herbario Mediterraneo, Palermo, 2014 (ISBN 978-88-85915-091). XXXII +208 pages; laminated flexible cover with flaps. [Received June 2014].

The original English edition of the Melbourne Code and its Spanish translation, published almost simultaneously at the end of 2012, have been reviewed in OPTIMA Newslett. 41: (22-23). 2013 (q.v.). Translations to Portuguese and Italian have now followed, both of which are their perfect typographical likeness as to cover and text. In both cases, one of the translators had participated actively in the preparation of the English edition; faithfulness of translation can therefore be safely assumed. The decisions taken by the Melbourne Congress have led to fairly important changes in the rules governing nomenclature and, additionally, have resulted in a substantial restructuring and rearrangement of an important chapter. It is therefore good to see the Melbourne Code translated to several languages relevant in the Mediterranean domain. To our knowledge, at least one more such translation, into Turkish, is in the pipeline

\section{Congresses and Meetings}

Franco Pedrotti \& Paolo Gerola (ed.) $-1^{\circ}{ }^{\circ}$ Congresso della Società Botanica Italiana onlus. Centro Congresso Piné 1000, Via C. Battisti, 98 Baselga di Piné (Trento), 18-20 settembre 2013. Riassunti. Relazioni - Comunicazioni - Posters. - Società Botanica Italiana, Firenze, 2013 (ISBN 978-8885915-07-7). 203 pages, figures, graphs, maps, tables; paper. [Received fall 2013].

Includes the scientific programme of the Congress, followed by abstracts of 24 lectures and 156 oral or poster presentations.

\section{Simonetta PeCCenINI \& Giannianto-} nio Domina (ed.) - Società Botanica Italiana, Gruppo per la Floristica. Contributi alla ricerca floristica in Italia. Comunicazioni. Orto Botanico, La Sapienza Università di Roma, 18-19 ottobre 2013. - Società Botanica Italiana, Firenze, 2013 (ISBN 978-88-85915-084). 56 pages, tables; paper. [Received October 2013].

Short versions of 21 papers presented at the annual meeting of the SBI Gruppo per la Floristica. For reviews of the abstract booklet for the 4 previous meetings, see OPTIMA Newslett. 39: (32). 2010; 40: (31-32). 2011; 41: (11-12). 2013. Disregarding the group's previously taken majority decision, three new combinations are again validly published 
in abstracts (genera Caroxylon and Helichrysum), but the intended name of a new subspecies is not, due to lack of English or Latin descriptive material.

Lorenzo Peruzzi \& Gianniantonio Domina (ed.) - Società Botanica Italiana, Gruppo per la Floristica, Sistematica ed Evoluzione. Floristica, sistematica ed evoluzione. Comunicazioni. Orto Botanico, La Sapienza Università di Roma, 21-22 novembre 2014. - Società Botanica Italiana, Firenze, 2014 (ISBN 978-88-85915-10-7). 52 pages, tables; paper. [Received November 2014].

Short versions (two pages each) of 23 papers presented at the annual meeting of the former SBI Gruppo per la Floristica, renamed for the occasion, with the title of the booklet reflecting the newly adopted name. The object of 19 of the paper is a single species or species group of the genera Allium, Amaranthus, Androsace, Anthemis, Bituminaria, Carduus, Corydalis, Crocus, Euphorbia, Gymnospermium, Helichrysum, Limonium (2), Pancratium, Pinguicula, Rhaponticoides, Sedum, Utricularia, Veronica; three have a regional focus: Central Apennine, Latium, Lombardy; and one concerns the Visiani herbarium in Padua.
Franco Pedrotti (ed.) - Stelvio '70. Biodiversità, dinamica del paesaggio e gestione delle aree montane. 8-11 settembre 2005. Rabbi (Trentino), Italia [Colloques phytosociologiques, 29.] Tipolitografia Editrice TEMI, Trento, 2013 (ISBN 978-88-97372-59-2). 799 pages, illustrations (some in colour), tables; hard cover. [25 €; received April 2014].

The Symposium "Stelvio '70" was held in the Rabbi valley, Trento Province, N. Italy, to commemorate the $70^{\text {th }}$ anniversary of the foundation of the Stelvio National Park. It had "Biodiversity. Landscape Dynamics and Management of Mountain Areas" as one of its three main themes. Papers presented in that section the manuscripts of which had been submitted before the end of 2005 (!) make up the present volume: 58 papers in English (28), Italian (22), French (6) or German (2), followed by a Guide to the Congress excursion. Some of the graytone pictures and graphs of the text reappear in colour at the end of the volume (pp. 767-796). Most papers are related to situations in the Alps, but some concern the Apennines, Sicily, Bulgaria, Russia, Caucasia and even Iran. 



\section{OPTIMA COMMISSIONS AND COMMITTEES}

\section{(2013-2019)}

\section{Commission on Bryophytes}

Secretary: R. M. Ros, Murcia

E-mail:rmros@um.es

\section{Commission for Common Names}

Secretary: M. Aghababyan, Erevan

E-mail: m_agababian@hotmail.com

\section{Commission for DNA Banking}

Chair: M. Bou Dagher Kharrat, Beirut

A. Scialabba, Palermo

E-mail: magda.boudagher@usj.edu.lb

\section{Commission for the conservation of Economically important and Endemic Plants}

Chair: V. H. Haywood, Reading

Secretary: J.M. Iriondo

E-mail : jose.iriondo@urjc.es

\section{Commission for the Diffusion on} Knowledge on Mediterranean Plants

Chair: O. Vasić, Beograd

Secretary: U. Plittman, Jerusalem

E-mail: uzi@vms.huji.ac.il

\section{Commission on Fungi}

Chair: G. Venturella, Palermo

Secretary: G. I. Zervakis, Athens

E-mail: zervakis@aua.gr

\section{Itinera Mediterranea Commission}

Chair: B. Valdés, Seville

Secretary: E. Vitek, Wien

E-mail: ernst.vitek@nhm-wien.ac.at

\section{Lichen Commission}

Secretary: A. R. Burgaz Moreno, Madrid

E-mail: arburgaz@bio.ucm.es

\author{
Commission on Mediterranean Type \\ Material
}

Chair: J. Molina, Montpellier

Secretary: G. Domina, Palermo

E-mail: gianniantonio.domina@unipa.it

\section{OPTIMA Herbarium and Library Commission}

Chair: W. Greuter, Palermo \& Berlin Secretary: F. M. Raimondo, Palermo E-mail : francesco.raimondo@unipa.it

\section{Commission for Karyosystematics and Molecular Systematics}

Chair: G. Kamari, Patras

Secretary: C. Blanché, Barcelona

E-mail : cesarblanche@ub.edu

\section{Prize Commission}

Secretary: G. Domina, Palermo

E-mail: gianniantonio.domina@unipa.it

Submission of contributions to OPTIMA Newsletter: Articles and news related to Mediterranean botany are welcome. Please send all texts as a Microsoft Word file to the pertinent Commission Secretary, or directly to the OPTIMA Secretariat. 
OPTIMA Newsletter 42

\section{Contents}

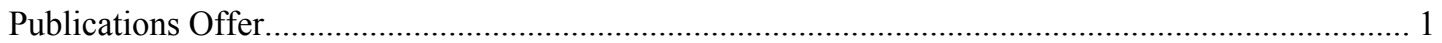

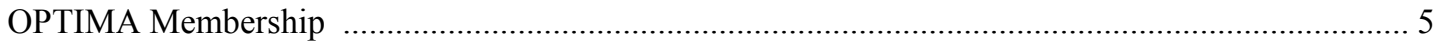

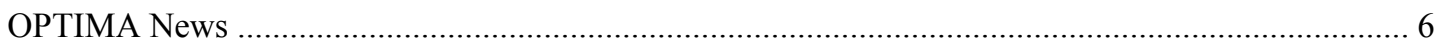

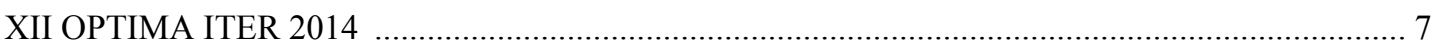

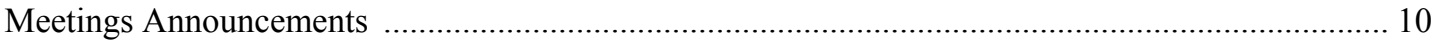

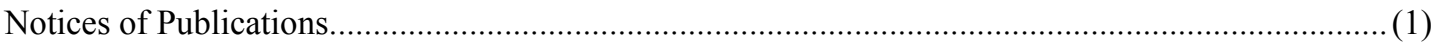

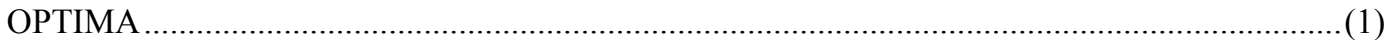

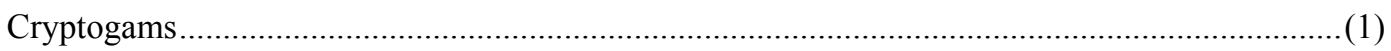

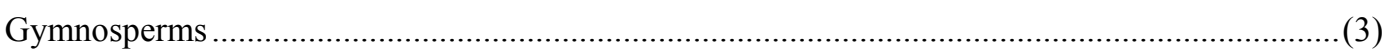

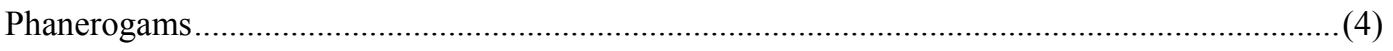

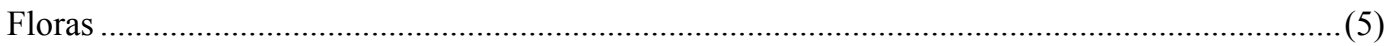

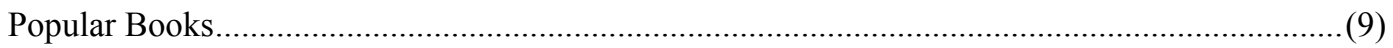

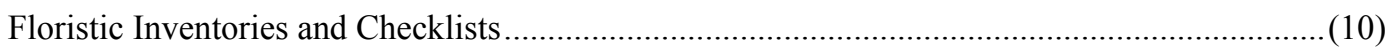

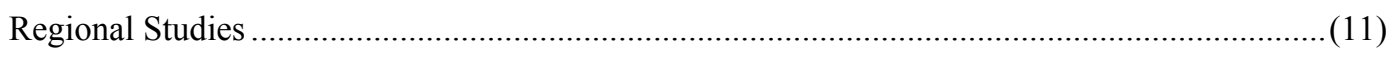

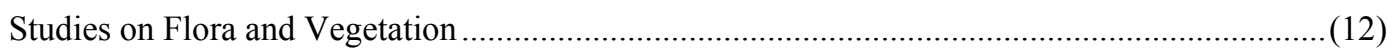

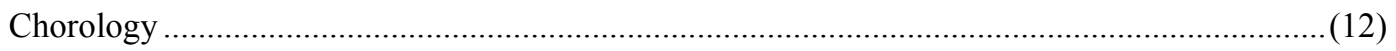

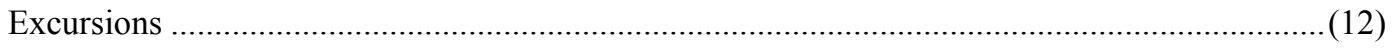

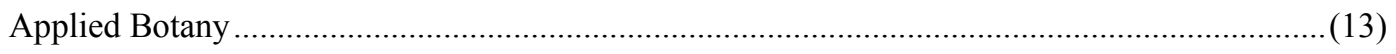

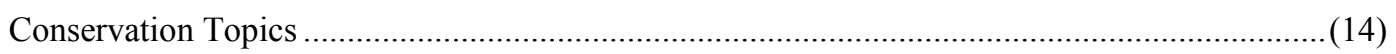

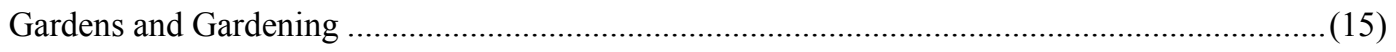

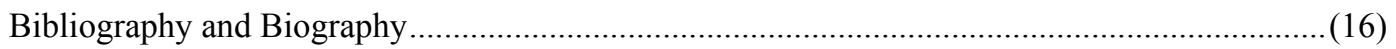

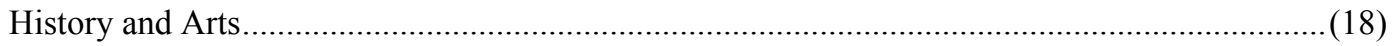

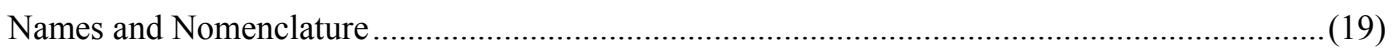

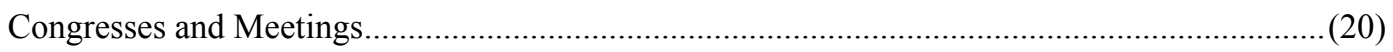

